\title{
An Assessment of Publisher Quality by Political Science Librarians
}

\author{
Janice S. Lewis
}

\begin{abstract}
Publisher quality is one criterion used by collection development librarians in making book selection decisions. Few studies have assessed the perceptions subject specialist librarians have about the quality of academic publishers' output in specific disciplines. The author surveyed a sample of members of the Association of College and Research Libraries Law \& Political Science Section, asking them to assess the overall quality of political science books published by sixty-two academic presses and imprints. The results are reported, analyzed, and compared to a similar survey of members of the American Political Science Association. Many similarities are seen in the rankings, although, on the whole, librarians ranked university presses higher and commercial publishers lower than did political scientists.
\end{abstract}

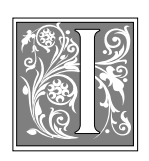

n 1997, more than seventy thousand books were published for the academic library market. More than two thousand political science titles, with an average cost of $\$ 51.76$, were included in this total. ${ }^{1}$ Choosing wisely from among these titles is a challenge for even experienced collection development librarians; for the novice, it can seem overwhelming. Making the task even more daunting is the fact that many college and university libraries have seen their budgets for books remain stagnant or even shrink, as serials and electronic resources consume a growing proportion of their budgets.

Generally, acquisition decisions in academic libraries are accomplished through both approval plans and individual orders. Approval plans define in advance the subjects, level of coverage, audience, treatment, language, price range, and publishers of books that the library wants to have shipped automatically to it. Although most approval plans provide for the return of books deemed inappropriate upon physical examination by library staff, actual return rates are usually low. Shelf-ready cataloging programs may make the likelihood of return even less.

As a supplement to approval plans, selectors at academic libraries make purchasing decisions for individual titles. Most individual purchasing decisions are based on an evaluation of a surrogate for the actual book, rather than an examination of the book itself. Sometimes the surrogate is an evaluative book review, but more often it is a listing in a publisher's catalog or a slip from the library's approval plan vendor that contains only minimal bibliographic and cataloging information. In this case, the selector must rely on his or her knowledge of the au-

Janice S. Lewis is the Coordinator of Instructional Services and Political Science Librarian in Joyner Library East Carolina University; e-mail: lewisja@mail.ecu.edu. 
thor, the publisher, any useful information imparted by the title, the described physical characteristics of the book, the price, the fit between the subject matter and the university's curricular and research needs, and any information given about the book's intended audience, format, and type.

Nearly all of these factors are specific to the individual title and provide little true insight into the comparative quality of two titles that, on the surface, may seem similar. In some cases, selectors may have some preexisting knowledge about an author; however, they can be expected to be familiar with only a small percentage of the hundreds of names they will see over the course of a year. The universe of publishers is relatively small compared with the number of authors, so over time, selectors may develop familiarity with publishers and make judgments about the quality of their output. A helpful aid to new selectors (and a useful basis for comparison and perhaps reinforcement or reconsideration for experienced selectors) would be studies that assess other selectors' perceptions of publisher quality in a particular discipline. Such studies also would be helpful when libraries set up or revise approval plan profiles and make decisions concerning which publishers to include.

\section{Review of the Literature}

Very few studies of publisher quality are available. In 1983, a study by John Calhoun and James K. Bracken, published in College $\mathcal{E}$ Research Libraries, reported the number of titles, number of outstanding book awards, and the ratio of awards to titles for the sixty publishers most often winning Choice Outstanding Academic Book awards for the years 1977-1981. In this study, Oxford and Cambridge each had an awards-to-total-titles-published ratio of 1:22 to 7 . Because most selectors know and respect these two academic publishers, this ratio was assigned an indexing value of 1.0 and all other publishers were ranked in relationship to it. The publishers with the ten highest indexing values were Harvard, Princeton, Temple, Yale, Indiana University, Cornell, Basic Books, Free Press, University of Chicago, and Thames \& Hudson. Those with the lowest values included large trade publishers such as Doubleday, Harper \& Row, McGraw-Hill, Prentice-Hall, and Random House. $^{2}$

In 1993, Edward A. Goedeken published a partial replication of the Calhoun and Bracken study, based on Choice data for the years 1988-1992. University presses increased their dominance of the Outstanding Academic Book awards during these years. These presses constituted twenty (331/3\%) of the top sixty publishers listed in 1983 and twenty-seven (45\%) in 1993. They accounted for 33 percent of the awards for 1977-1981 and 48 percent for 1988-1992. The publishers with the highest indexing values included Yale, Harvard, Princeton, University of California, University of North Carolina, Rutgers, Duke, Free Press, Indiana University, Cornell, and Abrams. Again, large trade publishers had the lowest indexing values. Goedeken noted that the design of the Calhoun-Bracken study made comparisons between university and commercial presses difficult because the commercial publishers' total output figures, which were used to calculate the awardto-title ratio and consequently the indexing value, included children's books, reprints, and other titles that were not aimed at the academic market. ${ }^{3}$

In 1996, Paul Metz and John Stemmer conducted a reputational survey of academic publishers. The authors acknowledged that attributing quality to a specific publisher's books represents an inherently subjective judgment. Accordingly, they attempted to assess as directly as possible the perceptions and opinions of their target group of "informed observers": the chief collection development officers at all ARL member institutions and at the seventy-two U. S. liberal arts colleges that constitute the Oberlin (Obergroup) institutions. Metz and Stemmer ranked sixty-four publishers according to the respondents' familiarity 
with the publisher, their perception of the relevance of the publisher's book titles to the academic community, and the overall intellectual and editorial quality of the publisher's monographic offerings. The top four rankings for both quality and relevance were claimed by university presses: Harvard, Cambridge, Oxford, and Stanford. For all publishers, perceptions of academic relevance were positively correlated with familiarity. Nearly all correlations between familiarity and quality were positive.

The authors found a large positive correlation between relevance and quality for most publishers. Nonetheless, a number of publishers showed a significant difference in perceptions of relevance and quality. One grouping consisted of publishers whose rankings for relevance were at least fifteen places greater than for quality. These publishers targeted the academic library marketplace, giving their titles a relevant scope almost by definition. This group included Greenwood, $\mathrm{M}$. E. Sharpe, University Press of America, and Westview. The second grouping was composed of publishers whose rankings were fifteen or more places higher for quality than for relevance. These publishers, including Atlantic Monthly Press, Alfred Knopf, Norton, Penguin, and Random House, were described as targeting the intellectual lay reader. ${ }^{4}$

In 1999, Larry P. Goodson, Bradford Dillman, and Anil Hira evaluated the quality of academic book publishers in political science. They surveyed a sample of American Political Science Association (APSA) members, asking them to assess the overall quality of political science books published by sixty-five presses and imprints. The publishers were taken from several sources, including two lists published in PS: Political Science and Politics. Criteria for inclusion in these lists were attendance and exhibits at major academic meetings and advertising in publications such as American Political Science Review. The authors added publishers that had exhibits at APSA meetings between 1995 and 1997, as well as publishers sug- gested by their university acquisitions librarians. This resulted in a list of more than 130 publishers, primarily located in the United States and Great Britain. They then eliminated small publishers (less than ten new political science books in 1997), "niche" publishers, and publishers whose primary products were not books and monographs. The final list contained twenty-nine university presses, thirtyfour commercial presses and imprints, and two others. Respondents were asked to evaluate the overall quality of each publisher's political science books by scoring them on a scale of zero to four (zero $=$ poor, one $=$ below average, two $=$ average, three $=$ above average, four $=$ excellent). Respondents were instructed to evaluate only those presses/imprints with which they were familiar. The survey was conducted via e-mail and was sent to 1,313 addresses; 347 usable responses were received.

Goodson, Dillman, and Hira found, as expected, that major university presses enjoyed the highest level of prestige as well as the greatest familiarity. In terms of quality, the top twelve publishers were major university presses; each also ranked within the top fiftieth percentile for familiarity. Commercial publishers claimed nine of the next ten highest rankings for quality. The remaining university and commercial publishers were interspersed throughout the ranking, with the bottom four places held by commercial presses.

The authors found that quality and familiarity are correlated strongly but do not always track together. Two university presses (North Carolina and Wisconsin), for example, ranked high on quality (twenty-two and twenty-three) but were known by less than half of the respondents. On the other hand, several presses that ranked low on quality were well known. McGraw-Hill and Greenwood, for example, were ranked twenty-two and twenty-eight, respectively, for familiarity but were forty-two and fifty-eight for quality.

The primary purpose of the APSA study was to identify the political science 
presses that members of the discipline viewed as publishing the highest-quality books so that association members could make more informed publishing choices. Because APSA members write textbooks as well as research titles, textbook publishers were included in the survey along with other commercial publishers and a large number of university presses. Comments from a number of survey respondents indicated that they felt it was not feasible to compare all these types of publishers on the same scale because the gap in quality was so great. However, the authors found that after the top dozen presses were set aside, the gap between different types of publishers was not great. For example, their results indicated that publishing with Routledge (nineteen quality, eighteen familiarity) or Sage (twenty quality, seven familiarity) should be more career enhancing than publishing with Temple (forty-seven quality, forty-seven familiarity) or Louisiana State (fifty-four quality, tied for fifty-five familiarity). ${ }^{5}$

\section{Members of ACRL's Law and \\ Political Science Section (LPSS) were identified as an appropriate audi- ence for the survey.}

Goodson, Dillman, and Hira concluded that "there is reputational capital in publishing" and that "with whom one publishes does matter." Political scientists attribute "a certain (and different) value, quality, and/or market niche" to books published by specific publishers. The value of these "trademarks" represents capital for authors, who assume some of the reputation of the houses with which they publish. ${ }^{6}$

The present article applies the methodology used in the APSA study to a targeted group of academic librarians who make collection development decisions for the discipline of political science. Together with the APSA study, it can provide useful information, albeit subjective, for librarians who need to evaluate publishers of political science books. In addi- tion, to the extent that some of the same publishers were included in the Metz and Stemmer study, the results can be compared to see what, if any, differences are seen in the surveyed librarians' perceptions of academic publishers in general and the perceptions of the quality of the publisher's output within the discipline of political science.

\section{Methodology}

Members of ACRL's Law and Political Science Section (LPSS) were identified as an appropriate audience for the survey. LPSS's purpose is to represent librarians in the fields of law and political science and to act for ACRL in cooperation with other professional groups in regard to those aspects of library service that require special knowledge of law and political science. ${ }^{7}$ A review of the membership roster for LPSS indicates that, in actuality, many of its members join because they are interested in the subject matter, even though their job responsibilities may encompass very different areas. To the extent that job titles were included on the LPSS membership roster, these were used to identify law librarians and other persons whose job responsibilities did not appear to include selection for the discipline of political science. Surveys were sent to persons whose listing on the roster identified them as social sciences, political science, public administration, or government documents librarians and to a sampling of those whose job responsibilities were not indicated on the roster or were very broad in scope (e.g., reference librarian or bibliographer). Three hundred surveys were mailed in October 1999. An e-mail reminder was posted to the LPSS listserv on November 17, 1999. Fifty-six persons returned surveys, of which forty-seven provided usable data, for a response rate of 18.66 percent.

Respondents were asked to evaluate the general quality of the political science books published by sixty-two major publishers by scoring them on a five-point scale. The publishers were taken from the APSA survey and thus were a variety of 


\begin{tabular}{|lc|}
\hline \multicolumn{2}{|c|}{ TABLE 1} \\
$\begin{array}{c}\text { Size of Acquisitions Budgets at } \\
\text { Respondents' Libraries }\end{array}$ \\
\hline \hline Budget Range & No. of Respondents \\
\hline$<\$ 500,000$ & 9 \\
$\$ 500,000-\$ 999,999$ & 11 \\
$\$ 1,000,000-\$ 3,000,000$ & 10 \\
$\$ 3,000,000-\$ 5,000,000$ & 6 \\
$\$ 5,000,000-\$ 7,000,000$ & 3 \\
Over $\$ 7,000,000$ & 7 \\
No response & 1 \\
\hline
\end{tabular}

large university and commercial presses whose primary products were books and monographs and which had exhibited at major political science academic meetings, advertised in publications such as American Political Science Review, or been suggested by acquisitions librarians at academic libraries. ${ }^{8}$ The zero to four rating scale was the same as that used in the APSA survey $($ zero $=$ poor, one $=$ below average, two $=$ average, three $=$ above average, four $=$ excellent). Respondents were instructed to evaluate only the publishers they were familiar with and to leave the space next to a publisher's name blank if they were not familiar with it. Space was provided for respondents to list other presses or imprints. If the recipient was not the appropriate person at the library to complete the questionnaire, he or she was asked to forward it to the person who was.

The survey included several questions on the background of the respondents and their institutions. Respondents were asked how many years they had been in their current position, in the library profession, and a member of LPSS. They also were asked to list their job title. In addition, they were asked to identify the approximate size of their library's acquisitions budget and the highest degree offered at the institution in the field of political science or public administration.

Those who answered the survey had been in their current position an average of 10.67 years, with a range of less than one year to thirty-seven years. They had been in the library profession an average of 18.5 years, with a range of less than one year to thirty-eight years. Several respondents were not members of LPSS, and others did not know how long they had been members. The most common job titles were bibliographer, government documents librarian, reference librarian, and social sciences librarian.

Table 1 shows the estimated acquisitions budget at respondents' institutions, and table 2 indicates the highest relevant degree offered at the institution.

\section{Results}

University presses had the highest rankings for quality, with the top twelve spots, and they claimed twenty-four of the top twenty-seven spots. Oxford topped the list with a mean of 3.81. It also had the lowest standard deviation, indicating that it was uniformly respected. The other highest-ranked university presses-Cambridge, Harvard, Johns Hopkins, Yale, University of Chicago, Columbia, and Cornell—each had mean quality rankings that exceeded 3.50. Congressional Quarterly, the highest ranking nonuniversity press, at number thirteen, was also the best-known publisher, with 96 percent of respondents indicating that they were familiar with it. ${ }^{9}$

At the top of the rankings, quality and familiarity tended to go hand in hand. However, five university presses that ranked in the top twenty for quality (New York University, University of North Carolina, University of Wisconsin, Penn

\begin{tabular}{|lc|}
\hline \multicolumn{2}{|c|}{ TABLE 2 } \\
Highest Academic Degree \\
Offered in Political Science or \\
Public Administration
\end{tabular}


TABLE 3

Perceptions of Academic Publisher Quality and Familiarity with Publisher

\begin{tabular}{|c|c|c|c|c|c|}
\hline Rank & Publisher & Mean & $\begin{array}{c}\text { Std. } \\
\text { Deviation }\end{array}$ & Median & Familiarity \\
\hline 1 & Oxford University Press & 3.81 & .39 & 4 & $91 \%$ \\
\hline 2 & Cambridge University Press & 3.71 & .45 & 4 & $87 \%$ \\
\hline 3 & Harvard University Press & 3.68 & .47 & 4 & $85 \%$ \\
\hline 4 & Johns Hopkins University Press & 3.64 & .48 & 4 & $83 \%$ \\
\hline 5 & Yale University Press & 3.63 & .53 & 4 & $85 \%$ \\
\hline 6 & University of Chicago Press & 3.58 & .59 & 4 & $85 \%$ \\
\hline 7 & Columbia University Press & 3.55 & .63 & 4 & $85 \%$ \\
\hline 8 & Cornell University Press & 3.54 & .60 & 4 & $74 \%$ \\
\hline 9 & Princeton University Press & 3.50 & .55 & 4 & $77 \%$ \\
\hline 10 & MIT Press & 3.49 & .65 & 4 & $74 \%$ \\
\hline 11 & New York University Press & 3.47 & .66 & 4 & $68 \%$ \\
\hline 12 & Stanford University Press & 3.45 & .68 & 4 & $81 \%$ \\
\hline 13 & Congressional Quarterly Press & 3.44 & .68 & 4 & $96 \%$ \\
\hline 14 & University of North Carolina Press & 3.42 & .61 & 3 & $66 \%$ \\
\hline 15 & University of California Press & 3.37 & .62 & 3 & $81 \%$ \\
\hline 16 & University of Wisconsin Press & 3.33 & .67 & 3 & $57 \%$ \\
\hline $\mathrm{t} 17$ & Duke University Press & 3.30 & .67 & 3 & $70 \%$ \\
\hline $\mathrm{t} 17$ & University Press of Virginia & 3.30 & .62 & 3 & $49 \%$ \\
\hline 19 & Penn State Press & 3.29 & .63 & 3 & $45 \%$ \\
\hline 20 & Westview Press & 3.24 & .82 & 3 & $70 \%$ \\
\hline $\mathrm{t} 21$ & Routledge & 3.23 & .80 & 3 & $83 \%$ \\
\hline t21 & University of Michigan Press & 3.23 & .72 & 3 & $74 \%$ \\
\hline 23 & Indiana University Press & 3.21 & .69 & 3 & $70 \%$ \\
\hline $\mathrm{t} 24$ & Temple University Press & 3.15 & .85 & 3 & $57 \%$ \\
\hline $\mathrm{t} 24$ & University of Illinois Press & 3.15 & .66 & 3 & $70 \%$ \\
\hline $\mathrm{t} 24$ & University of Pittsburgh Press & 3.15 & .52 & 3 & $57 \%$ \\
\hline 27 & State University of New York Press & 3.13 & .72 & 3 & $64 \%$ \\
\hline 28 & West Publishing Company & 3.09 & .72 & 3 & $68 \%$ \\
\hline 29 & Blackwell Publishers & 3.03 & .70 & 3 & $74 \%$ \\
\hline 30 & M.E. Sharpe, Inc. & 3.00 & .75 & 3 & $68 \%$ \\
\hline 31 & St. Martin's Press & 2.97 & .75 & 3 & $72 \%$ \\
\hline 32 & Louisiana State University Press & 2.93 & .72 & 3 & $57 \%$ \\
\hline 33 & Lynne Rienner Publishers & 2.89 & .82 & 3 & $60 \%$ \\
\hline 34 & Rowman \& Littlefield & 2.86 & .79 & 3 & $60 \%$ \\
\hline 35 & MacMillan & 2.85 & .78 & 3 & $70 \%$ \\
\hline 36 & University of Missouri Press & 2.83 & .75 & 3 & $51 \%$ \\
\hline 37 & University Press of Florida & 2.81 & .79 & 3 & $45 \%$ \\
\hline $\mathrm{t} 38$ & Sage Publications, Inc. & 2.80 & .82 & 3 & $74 \%$ \\
\hline $\mathrm{t} 38$ & Transaction Press & 2.80 & .91 & 3 & $64 \%$ \\
\hline 40 & Greenwood Publishing Group & 2.78 & .78 & 3 & $79 \%$ \\
\hline $\mathrm{t} 41$ & University of South Carolina Press & 2.75 & .70 & 3 & $43 \%$ \\
\hline $\mathrm{t} 41$ & Markus Weiner Publishers & 2.75 & .66 & 3 & $17 \%$ \\
\hline 43 & Longman Publishing Group & 2.64 & .89 & 3 & $53 \%$ \\
\hline 44 & W.W. Norton and Company & 2.62 & .77 & 3 & $72 \%$ \\
\hline 45 & Basic Books & 2.56 & .79 & 3 & $68 \%$ \\
\hline 46 & Humanities Press & 2.53 & .82 & 3 & $40 \%$ \\
\hline
\end{tabular}




\begin{tabular}{|c|c|c|c|c|c|}
\hline \multicolumn{6}{|c|}{$\begin{array}{c}\text { TABLE } 3 \text { (CONT.) } \\
\text { Perceptions of Academic Publisher Quality and Familiarity with Publisher }\end{array}$} \\
\hline Rank & Publisher & Mean & $\begin{array}{c}\text { Std. } \\
\text { Deviation }\end{array}$ & Median & Familiarity \\
\hline 47 & Penguin Putnam Inc. & 2.52 & .62 & 2 & $62 \%$ \\
\hline 48 & Simon and Schuster & 2.47 & .78 & 2 & $72 \%$ \\
\hline 49 & Prentice Hall & 2.45 & .72 & 2 & $62 \%$ \\
\hline 50 & Chatham House Publishers & 2.43 & .90 & 2 & $45 \%$ \\
\hline 51 & McGraw-Hill, Inc. & 2.42 & .82 & 2 & $70 \%$ \\
\hline 52 & Houghton-Mifflin Company & 2.40 & .84 & 2 & $64 \%$ \\
\hline 53 & Ashgate Publishing Company & 2.38 & .84 & 2 & $45 \%$ \\
\hline 54 & Frank Cass Publishers & 2.37 & .67 & 2 & $40 \%$ \\
\hline 55 & Wadsworth Publishing Company & 2.36 & .64 & 2 & $47 \%$ \\
\hline 56 & Random House, Inc. & 2.31 & .71 & 2 & $74 \%$ \\
\hline 57 & Allyn \& Bacon & 2.30 & .71 & 2 & $57 \%$ \\
\hline 58 & University Press of America & 2.23 & .94 & 2 & $66 \%$ \\
\hline 59 & Nelson-Hall, Inc. & 2.21 & .56 & 2 & $30 \%$ \\
\hline 60 & HarperCollins College Publishers & 2.17 & .73 & 2 & $64 \%$ \\
\hline 61 & Harcourt Brace College Publishers & 2.14 & .63 & 2 & $62 \%$ \\
\hline 62 & D.C. Heath & 1.94 & .78 & 2 & $38 \%$ \\
\hline
\end{tabular}

State, and University Press of Virginia) were in the middle of the pack in terms of familiarity. Likewise, several wellknown commercial presses ranked relatively low on quality. Random House, for example, was familiar to 74 percent of respondents but was ranked fifty-sixth for quality.

\section{Because textbook purchases are generally not a priority, librarians' perceptions of the quality of text- book publishers are likely to suffer as well.}

Respondents' familiarity with surveyed publishers ranged from 96 percent for Congressional Quarterly to 17 percent for Markus Weiner Publishers. Just over one-half of the publishers were familiar to at least two-thirds of the respondents. Eighty percent of the publishers were familiar to at least one-half of the respondents. Table 3 shows the rank, mean, standard deviation, median, and percentage of respondents familiar with each publisher.

University presses, and particularly Canadian university presses not repre- sented in the study, received the most "write-in" votes. Two respondents ranked University of Toronto as "excellent." University of Kansas, University of Iowa, University of Washington, McGillQueen's University, University of New Mexico, University of Oklahoma, and the Council on Foreign Relations Press each was ranked "excellent" by one respondent. Kluwer Academic Publishers, University of Alberta, and Foundation Press received one ranking each as "above average," while one respondent listed University of Calgary as "average."

Table 4 compares publishers' rankings by APSA members and LPSS members. The last column shows the differential in numerical rank between the two groups. Overall, university presses faired even better in terms of quality rankings in this study than in the APSA study. Not only are more of the top spots claimed by university presses, all of them fall into the top two-thirds of the quality ranking. The bottom third of the APSA quality-ranking list included seven university presses. Not surprisingly, many textbook publishers, including Houghton Mifflin Company, Harcourt Brace College Publishers, 
TABLE 4

Comparison of APSA and LPSS Rankings for Publisher Quality

\begin{tabular}{|c|c|c|c|c|c|}
\hline $\begin{array}{l}\text { APSA } \\
\text { Rank }\end{array}$ & $\begin{array}{l}\text { APSA } \\
\text { Mean }\end{array}$ & Publisher & $\begin{array}{l}\text { LPSS } \\
\text { Rank }\end{array}$ & $\begin{array}{l}\text { LPSS } \\
\text { Mean }\end{array}$ & $\begin{array}{c}\text { Ranking } \\
\text { Differential }\end{array}$ \\
\hline 1 & 3.72 & Cambridge University Press & 2 & 3.71 & -1 \\
\hline 2 & 3.61 & Princeton University Press & 9 & 3.5 & -7 \\
\hline $\mathrm{t} 3$ & 3.56 & Oxford University Press & 1 & 3.81 & 2 \\
\hline $\mathrm{t} 3$ & 3.56 & University of Chicago Press & 6 & 3.58 & -3 \\
\hline 5 & 3.48 & Yale University Press & 5 & 3.63 & 0 \\
\hline 6 & 3.46 & Harvard University Press & 3 & 3.68 & 3 \\
\hline 7 & 3.31 & University of California Press & 15 & 3.37 & -8 \\
\hline 8 & 3.24 & Cornell University Press & 8 & 3.54 & 0 \\
\hline 9 & 3.19 & University of Michigan Press & $\mathrm{t} 21$ & 3.23 & -12 \\
\hline 10 & 3.09 & MIT Press & 10 & 3.49 & 0 \\
\hline 11 & 3.06 & Stanford University Press & 12 & 3.45 & -1 \\
\hline 12 & 3.05 & Johns Hopkins University Press & 4 & 3.64 & 8 \\
\hline 13 & 3.04 & Brookings Institution & & & \\
\hline 14 & 3.02 & Columbia University Press & 7 & 3.55 & 7 \\
\hline 15 & 2.93 & Congressional Quarterly Press & 13 & 3.44 & 2 \\
\hline 16 & 2.81 & Basic Books & 45 & 2.56 & -29 \\
\hline $\mathrm{t} 17$ & 2.78 & W.W. Norton and Company & 44 & 2.62 & -27 \\
\hline $\mathrm{t} 17$ & 2.78 & Blackwell Publishers & 29 & 3.03 & -12 \\
\hline 19 & 2.74 & Routledge & $\mathrm{t} 21$ & 3.23 & -2 \\
\hline $\mathrm{t} 20$ & 2.71 & Sage Publications, Inc. & $\mathrm{t} 38$ & 2.8 & -18 \\
\hline $\mathrm{t} 20$ & 2.71 & St. Martin's Press & 31 & 2.97 & -11 \\
\hline 22 & 2.65 & University of North Carolina Press & 14 & 3.42 & 8 \\
\hline $\mathrm{t} 23$ & 2.63 & Duke University Press & $\mathrm{t} 17$ & 3.3 & 6 \\
\hline $\mathrm{t} 23$ & 2.63 & University of Wisconsin Press & 16 & 3.33 & 7 \\
\hline 25 & 2.61 & Penguin Putnam Inc. & 47 & 2.52 & -22 \\
\hline 26 & 2.59 & Westview Press & 20 & 3.24 & 6 \\
\hline 27 & 2.56 & Houghton Mifflin Company & 52 & 2.4 & -25 \\
\hline 28 & 2.54 & Chatham House Publishers & 50 & 2.43 & -22 \\
\hline 29 & 2.51 & New York University Press & 11 & 3.47 & 18 \\
\hline $\mathrm{t} 30$ & 2.5 & University of Pittsburgh Press & $\mathrm{t} 24$ & 3.15 & 6 \\
\hline $\mathrm{t} 30$ & 2.5 & Random House, Inc. & 56 & 2.31 & -26 \\
\hline $\mathrm{t} 30$ & 2.5 & Rowman \& Littlefield & 34 & 2.86 & -4 \\
\hline $\mathrm{t} 33$ & 2.49 & Indiana University Press & 23 & 3.21 & 10 \\
\hline $\mathrm{t} 33$ & 2.49 & HarperCollins College Publishers & 60 & 2.17 & -27 \\
\hline $\mathrm{t} 35$ & 2.48 & Lynne Rienner Publishers & 33 & 2.89 & 2 \\
\hline $\mathrm{t} 35$ & 2.48 & Simon and Schuster & 48 & 2.47 & -13 \\
\hline 37 & 2.47 & West Publishing Company & 28 & 3.09 & 9 \\
\hline $\mathrm{t} 38$ & 2.46 & Prentice Hall & 49 & 2.45 & -11 \\
\hline $\mathrm{t} 38$ & 2.46 & Macmillan & 35 & 2.85 & 3 \\
\hline 40 & 2.4 & State University of New York Press & 27 & 3.13 & 13 \\
\hline 41 & 2.39 & Penn State Press & 19 & 3.29 & 22 \\
\hline 42 & 2.37 & McGraw-Hill, Inc. & 51 & 2.42 & -9 \\
\hline 43 & 2.35 & Longman Publishing Group & 43 & 2.64 & 0 \\
\hline 44 & 2.32 & University of Illinois Press & $\mathrm{t} 24$ & 3.15 & 20 \\
\hline 45 & 2.31 & Harcourt Brace College Publishers & 61 & 2.14 & -16 \\
\hline 46 & 2.3 & M.E. Sharpe, Inc. & 30 & 3 & 16 \\
\hline
\end{tabular}




\begin{tabular}{|c|c|c|c|c|c|}
\hline \multicolumn{6}{|c|}{$\begin{array}{l}\text { TABLE } 4 \text { (CONT) } \\
\text { Comparison of APSA and LPSS Rankings for Publisher Quality }\end{array}$} \\
\hline $\begin{array}{l}\text { APSA } \\
\text { Rank }\end{array}$ & $\begin{array}{l}\text { APSA } \\
\text { Mean }\end{array}$ & Publisher & $\begin{array}{l}\text { LPSS } \\
\text { Rank }\end{array}$ & $\begin{array}{l}\text { LPSS } \\
\text { Mean }\end{array}$ & $\begin{array}{c}\text { Ranking } \\
\text { Differential }\end{array}$ \\
\hline 47 & 2.26 & Temple University Press & $\mathrm{t} 24$ & 3.15 & 23 \\
\hline 48 & 2.25 & Kluwer & & & \\
\hline 49 & 2.16 & University Press of Virginia & $\mathrm{t} 17$ & 3.3 & 32 \\
\hline 50 & 2.14 & United States Institute of Peace & & & \\
\hline 51 & 2.11 & Allyn \& Bacon & 57 & 2.3 & -6 \\
\hline 52 & 2.09 & Wadsworth Publishing Company & 55 & 2.36 & -3 \\
\hline 53 & 2.08 & Frank Cass Publishers & 54 & 2.37 & -1 \\
\hline 54 & 2.03 & Louisiana State University Press & 32 & 2.93 & 22 \\
\hline 55 & 2.02 & Transaction Publishers & $\mathrm{t} 38$ & 2.8 & 17 \\
\hline 56 & 2 & University of South Carolina Press & s $t 41$ & 2.75 & 15 \\
\hline 57 & 1.96 & D.C. Heath & 62 & 1.94 & -5 \\
\hline 58 & 1.95 & Greenwood Publishing Group & 40 & 2.78 & 18 \\
\hline 59 & 1.91 & University of Missouri Press & 36 & 2.83 & 23 \\
\hline 60 & 1.86 & Nelson-Hall, Inc. & 59 & 2.21 & 1 \\
\hline 61 & 1.83 & University Press of Florida & 37 & 2.81 & 24 \\
\hline 62 & 1.81 & Humanities Press & 46 & 2.53 & 16 \\
\hline 63 & 1.51 & University Press of America & 58 & 2.23 & 5 \\
\hline t64 & 1.47 & Markus Weiner Publishers & $\mathrm{t} 41$ & 2.75 & 23 \\
\hline t64 & 1.47 & Ashgate Publishing Company & 53 & 2.38 & 11 \\
\hline
\end{tabular}

and Chatham House, ranked at least fifteen places lower in the present survey than in the Goodson study. Most academic libraries do not purchase textbooks, and if they do, they are likely to purchase textbooks specifically because they are used in courses taught on campus. In such cases, the publisher is irrelevant. Because textbook purchases are generally not a priority, librarians' perceptions of the quality of textbook publishers are likely to suffer as well. In addition, political science professors are more likely to have compared the relative quality of textbooks as they make selections for courses and possibly shop for a publisher for a textbook they authored.

Some commercial publishers were ranked relatively high for quality on both lists. For example, Congressional Quarterly, Blackwell, Routledge, Westview, and St. Martin were in the top 50 percent on both lists. However, there were clear differences of opinion between members of LPSS and members of APSA regarding the quality of some commercial publish- ers. LPSS members ranked Basic, HarperCollins, Norton, Penguin, and Sage at least fifteen points lower than APSA members did but ranked Greenwood, Humanities, Markus Weiner, M. E. Sharpe, Transaction, Ashgate, and West higher.

Twenty-seven of the sixty-two publishers included in the survey also were included in Metz and Stemmer's reputational study of academic publishers. Table 5 lists the common publishers in order of quality ranking in each study. The rankings show noticeable similarities, with rankings varying by only a few places for most publishers. The largest variations in rank are seen for five commercial publishers: Norton, Basic, and Random House were ranked higher in the Metz and Stemmer study, whereas M. E. Sharpe and Westview were ranked higher in the LPSS study. In the Metz and Stemmer study, Norton and Random House were included in a cluster of publishers that targeted the "upper-brow" lay reader, so characterized because they 
TABLE 5

Comparison of Publishers' Rankings in LPSS and Metz \& Stemmer Studies

\section{LPSS Study}

Oxford University Press

Cambridge University Press

Harvard University Press

Stanford University Press

Westview Press

Routledge

State University of New York Press

Blackwell Publishers

M.E. Sharpe, Inc.

St. Martin's Press

MacMillan

Sage Publications, Inc.

Transaction Publishers

Greenwood Publishing Group

W.W. Norton and Company

Basic Books

Humanities Press

Penguin Putnam Inc.

Simon and Schuster

Prentice Hall

McGraw-Hill, Inc.

Houghton Mifflin Company

Ashgate Publishing Company

Random House, Inc.

Allyn \& Bacon

University Press of America

HarperCollins College Publishers

\section{Metz \& Stemmer Study}

Harvard University Press

Cambridge University Press

Oxford University Press

Stanford University Press

Blackwell Publishers

Routledge

W.W. Norton and Company

Basic Books

State University of New York Press

St. Martin's Press

Sage Publications, Inc.

MacMillan

Penguin

Random House, Inc.

Humanities Press

Westview

McGraw-Hill

Transaction Publishers

Houghton Mifflin Company

Greenwood Publishing Group

M.E. Sharpe, Inc.

Simon and Schuster

Prentice Hall

Allyn \& Bacon

HarperCollins

Ashgate Publishing Company

United Press of America ranked fifteen or more places higher for quality than for relevance. Perhaps the lesser degree of relevance of these publishers' political science titles to the academic market helped account for their lower ranking in the LPSS study, in which relevance and quality were not differentiated.

The present study was conducted with the hope that it could help inform political science librarians' collection development decisions by providing information as to how their colleagues ranked a num- ber of publishers based on the quality of their output in the field of political science. Particularly where the LPSS, APSA, and Metz and Stemmer studies show consistencies, political science collection development librarians may find the opinions of their academic colleagues valuable. Even so, the careful selector will recognize the variations in quality among books produced by the same publisher and continue to use all the tools at his or her disposal to make the most-informed acquisition decisions possible.

\section{Notes}

1. Dave Bogart, ed., The Bowker Annual, 44th ed. (New Providence, R.I.: R.R. Bowker, 1999), 508-9.

2. John Calhoun and James K. Bracken, "An Index of Publisher Quality for the Academic 
Library," College \& Research Libraries 44 (May 1983): 257-59.

3. Edward A. Goedeken, "An Index to Publisher Quality Revisited: A Partial Replication," Library Acquisitions: Practice \& Theory 17 (fall 1993): 263-68.

4. Paul Metz and John Stemmer, "A Reputational Study of Academic Publishers," College \& Research Libraries 57 (May 1996): 234-47.

5. Larry P. Goodson, Bradford Dillman, and Anil Hira, "Ranking the Presses: Political Scientists' Evaluations of Publisher Quality," PS-Political Science \& Politics 32 (June 1999): 257-62.

Ibid., 261.

7. "Law and Political Science Section Bylaws," 1982 [Internet, WWW] , available at: http:// facstaff.uww.edu/hansenc/lpssbylw.htm. Accessed Feb. 11, 2000.

8. Anil Hira, one of the authors of the Goodson et al study, kindly supplied the author with a draft copy of their survey. This draft contained a list of sixty-two publishers. It was used as the source for the publishers included on the survey mailed to LPSS members. Goodson, Dillman, and Hira apparently added three publishers (Brookings Institution, Kluwer, and United States Institute of Peace) before actually conducting their survey.

9. Congressional Quarterly Press is a well-known publisher of reference titles and other books relevant to government, political science, and public administration. It is a regular exhibitor at ALA and ACRL meetings and conventions and distributes its catalogs widely. In light of the audience surveyed, however, it should be noted that LPSS and Congressional Quarterly have a special relationship that could affect its familiarity with LPSS members. Congressional Quarterly sponsors the Marta Lange/CQ award, given each year to an outstanding academic or law librarian selected by LPSS. 